\title{
New data on Aricia agestis (Lepidoptera: Lycaenidae), its life history and occurrence in the Podkarpacie region of Poland
}

\author{
Jarosław BURY
}

Markowa 1498, 37-120 Markowa, Poland; e-mail: jarekbury2@wp.pl

\begin{abstract}
Aricia agestis (Lycaenidae) is a widespread and not endangered species, however its biology is poorly known in Poland. Helianthemum nummularium L. (Cistaceae) and Erodium cicutarium L., Geranium pratense L., Geranium sanquineum L., and Geranium pusilum L. (Geraniaceae) were mentioned as larval host plants from Poland so far, but no data about preimaginal stages of the species were known from south-eastern part of the country. From 2009 up to 2014 many new records of imagines of A. agestis were revealed in mountain and sub-mountain zones of Podkarpacie region, where A. agestis was known from few isolated localities. Additionally, during the observations carried out in 2012 in central and south Podkarpacie region, eggs and early instar caterpillars (L1 \& L2) of the second generation were found for the first time in nature on Geranium phaeum L. (Lipnik), and their occurrence on $G$. pratense L. was detected at the locality of Markowa. Interactions of caterpillars with ants were not recorded. In conclusion, A. agestis is in expansion in mountain and sub-mountain zones of Podkarpacie region (south-eastern Poland) and Geranium phaeum L. is established as the new larval host plants of A. agestis from Poland.
\end{abstract}

Key words: expansion range, host plant, Geranium phaeum, life history, Polish Carpathian Foothills, south-eastern Poland

\section{INTRODUCTION}

Aricia agestis, is a species of the family of blues (Lycaenidae), showing a west and central Palearctic type of distribution. The species is found over the area spanning from northern Spain, through Central and Southern Europe, including Corsica, Sicily and Crete, in west and central Russia, Asia Minor, the countries of the Middle East and the Central Asia, up to the Altai and Tien Shan on the east (Hesselbarth et al. 1995; Tolman \& Lewington 1997; Tshikolovets 1998, 2003, 2005; Tuzov et al. 2000; Kudrna 2002; Tshikolovets et al. 2009; Kudrna et al. 2011; Setelle et al. 2011). On the Pyrenean Peninsula, on Sardinia, and in Northern Africa, occurs a closely related taxon of Aricia cramera (Eschschultz, 1821), which was treated as a separated species or as subspecies of A. agestis (Tolman \& Lewington 1997, Lafranchis 2004, Tarrier \& Delacre 2008, Sañudo-Restrepo et al. 2012, Vodă et al. 2015).

The butterflies emerge in two, sometimes three generations - between the first half of May till the end June, from the first half of July till the end of August, and - sometimes - in rudimentary form the first half of September till mid-October. Outside Poland, in the northern parts of the range, populations are recorded in a single generation per year, e.g. in the Great Britain, and Latvia (Tolman \& Lewington 1997, Aagaard et al. 2002).

In conditions prevailing in central and north Poland, the females lay eggs on common rock-rose (Helianthemum nummularium L.) (Cistaceae), and also on common stork's bill (Erodium cicutarium L.), as well as on several species of geranium: meadow geranium (Geranium pratense L.), bloody geranium (Geranium sanguineum L.), and small geranium (Geranium pusillum L.) (Geraniaceae) (Bury 2010, Buszko \& Olszewski 2010, Olszewski 2010, Warecki 2010).

According to some unconfirmed Polish reports, also other species of Geranium, native to Poland, such as: cut-leaf geranium (Geranium dissectum L.), dove's-foot geranium (Geranium 
molle L.), wood geranium (Geranium sylvaticum L.), and marsh geranium (Geranium palustre L.) can be listed as host plants (Ebert 1991, Tshikolovets 2003, Nekrutenko \& Tshikolovets 2005, Buszko \& Masłowski 2008, Sielezniew \& Dziekańska 2010). Romaniszyn (1929) and Krzywicki (1982) reported cornflowers (Centaurea spp.) as potential host plants for larvae of A. agestis, but it has never been confirmed by observations from Poland. Also known is a report of the possibility that $A$. agestis larvae feed on pelargonium (Pelargonium spp.) (Allan 1949).

The caterpillars in the early developmental stages (L1, L2, L3) initially feed on the lower surfaces of leaves of host plants, cutting characteristic window-shaped cavities in the lower cuticle. Older caterpillars (L4) eat up the whole leaf blades. Pupation occurs in litter at the base of host plants. The larvae of $A$. agestis have the organs called pore cupola organs (PCOs), preventing aggression from ants, dorsal nectary organs (DNOs), and the tympanal organs (TOs), allowing them to enter facultative myrmecophily-type relations with ants. To date, the caterpillars of $A$. agestis were observed accompanied by ants of the genera Myrmica L. and Lasius Fabr. (Fiedler 1991, 1994, 1995; Fiedler \& Hummel 1995; Fiedler 2006). The pupae, capable of stridulation, can be buried in underground chambers or brought to ant nests by the ants accompanying them. The degree of pupae myrmecophily is still unclear (Fiedler 1995).

The morphological description of imago and preimaginal stages was provided by Krzywicki (1959, 1982), Tolman \& Lewington (1997), Lafranchis (2004), Buszko \& Masłowski (2008), Bury (2010), Olszewski (2010) and Sielezniew \& Dziekańska (2010).

In Poland, A. agestis is recorded on almost entire territory, however, in mountainous regions it is much rarer than in the lowlands (Buszko \& Masłowski 1993, Buszko 1997, Przybyłowicz 2000, Buszko \& Masłowski 2008, KSIB 2015, Čížek et al. 2015). The species prefers dry habitats, on sandy or calcareous substrates; it is found chiefly on meadows, fallow lands, heaths, forest edges, forest glades, road and railway embankments, in ruderal areas, or even in home gardens. Much more rarely, this species is found in moist habitats, e.g. boggy meadows (Buszko \& Masłowski 2008, Bury 2010, Olszewski 2010, Warecki 2010).

The Podkarpacie region is a very special area within Poland from the viewpoint of feeding plants for $A$. agestis larvae, because of almost complete absence of common rock-rose, and limited occurrence of common stork's bill - the two prinicipal host plants for this butterfly species (Zając \& Zając 2001). Among the species of Geranium L. genus, listed in the references to date as the species associated with the larvae of $A$. agestis in the Podkarpacie area, the following species are cited: meadow geranium, cut-leaf geranium, dove's-foot, small geranium, bloody geranium, wood geranium, and marsh geranium, with the last three species recorded in the Podkarpacie region only very rarely, whereas small geranium occurs in low numbers (Zając \& Zając 2001, Bury 2010, Buszko \& Olszewski 2010, Olszewski 2010).

The aim of my study was to investigate the A. agestis distribution on mountain and submountain zone of Podkarpacie region (the Polish Carpathian Foothills) and (in the connection to the lack of any earlier data) to recognize the host plants used by A. agestis larvae under conditions prevailing in this part of Poland.

\section{MATERIAL AND METHODS}

Data gathered during field observations of the species Aricia agestis (Denis \& Schiffermüller, 1775) conducted in mountain and sub-mountain zones of Podkarpacie region in 2009-2014 are presented below. The insects were observed live in their natural habitat, the observations were documented using digital cameras. The names of $(\bullet)$ macro- and $(-)$ mesoregions follow The Regional Geography of Poland (Kondracki 2002), and (•) UTM (Universal Transverse of Mercator) in a network of $10 \times 10 \mathrm{~km}$ fields, whereas for locations 
where preimaginal stages were observed, the geographical coordinates in DNS format are also supplied. The distribution of newly discovered localities of $A$. agestis, against the background of the earlier data are shown on the map (Fig. 1).

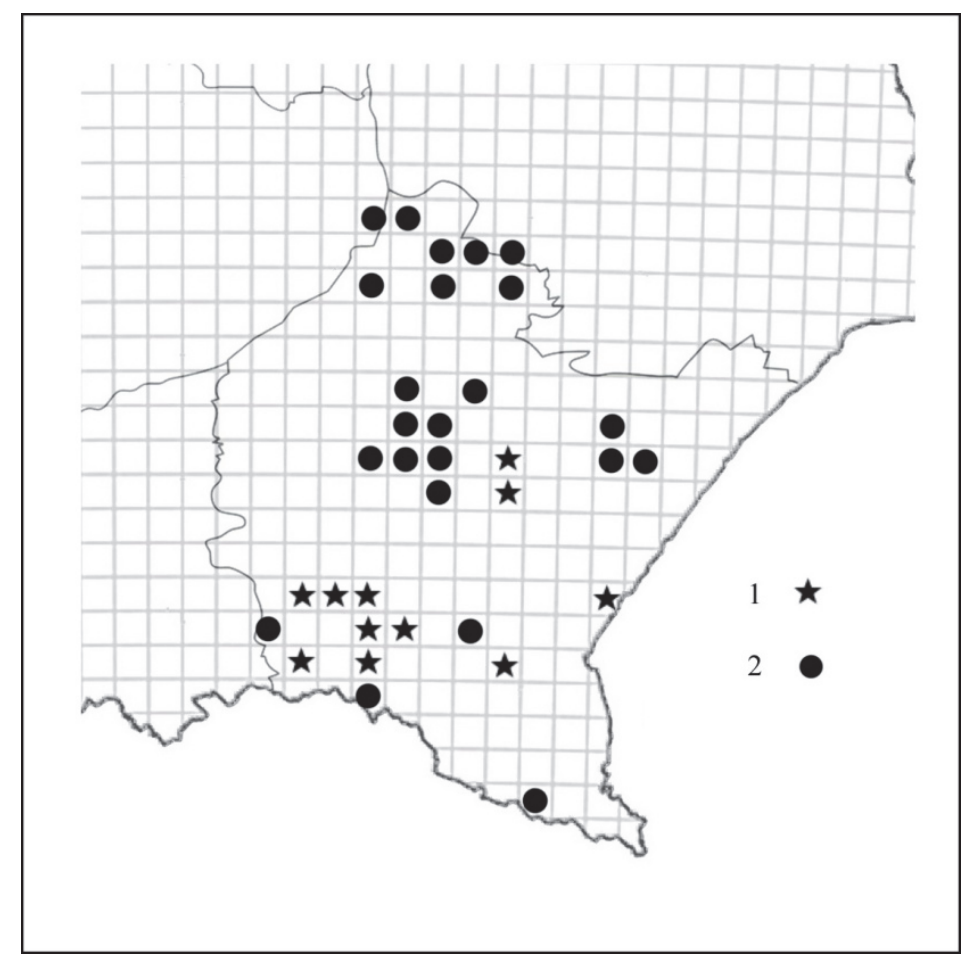

Fig. 1. Distribution of Aricia agestis in Podkarpacie region known before 2014. 1 - new data from the years 2009-2014; 2 data from literature. Clear map with UTM gird $(10 \times 10 \mathrm{~km})$ downloaded from: http://download.entomo.pl/UTM/prgmapautm/

\section{RESULTS}

\section{Observations of imagines}

- Pogórze Środkowobeskidzkie/Beskidy Środkowe (Beskidy Środkowe Foothills/Beskidy Środkowe Mts)

- Pogórze Bukowskie/Beskid Niski (Bukowsko Foothills/Low Beskid Mts)

- EV69: Rymanów, 27 Jul 2009, 1 specimen, obs. W. Guzik

- Pogórze Środkowobeskidzkie (Beskidy Środkowe Foothills)

- Pogórze Bukowskie (Bukowsko Foothills)

- EV69: Ladzin, 27 Jul 2009, 1 specimen, obs. W. Guzik

- EV59: Miejsce Piastowe, 23 Jul 2012, 1 specimen, obs. W. Guzik

- EV59: Wrocanka, 4 Aug 2011, 1 specimen, obs. W. Guzik

- Pogórze Środkowobeskidzkie (Beskidy Środkowe Foothills)

- Kotlina Jasielsko-Krośnieńska/Pogórze Bukowskie (Jasło-Krosno Valley/Bukowsko Foothills)

- EA30: Umieszcz, 3 Jun 2011, 23 Jun 2011, 23 May 2013, several specimens, obs. K. Mazur 
- EA40: Glinik Polski, 3 Jun 2011, 14 August 2011, 3 Sep 2012, 19 Jul 2013, several specimens, obs. K. Mazur

- EA50: Krosno, 15 Jun 2010, 1 specimen, 26 Jun 2011, 1 specimen, 8 Jul 2011, 1 specimen, 4 Jul 2012, 1 specimen, obs. W. Guzik

- EA50: Głowienka, 26 May 2012, 1 specimen, obs. W. Guzik

- Beskidy Środkowe (Beskidy Środkowe Foothills)

- Beskid Niski (Low Beskid Mts)

- EV38: Krempna, 4 Jul 2011, 22 Aug 2011, several specimens, obs. K. Mazur

- EV58: Jasionka, 8 Jun 2013, 1 specimen, obs. D. Stasiowski

- Kotlina Sandomierska/Pogórze Środkowobeskidzkie (Sandomierz Valley/Beskidy Środkowe Foothills)

- Przedgórze Rzeszowskie/Pogórze Dynowskie (Rzeszów Foreland/Dynów Foothills)

- EA94 Markowa, 9 Jul 2010, c. 20 specimens, 8 Aug 2011, 1 specimen, 22 Jul 2012, 1 specimen in a flower/vegetable garden, 24 Jul 2012, 1 male in home garden, 27 Jul 2012, several specimens, 29 Jul 2012, several specimens on a meadow, 6 Aug 2012, several specimens, obs. J. Bury

- EA93 Lipnik (n. Kańczuga), 1 Aug 2012, several specimens in an orchard, obs. J. Bury

- Pogórze Środkowebeskidzkie/Beskidy Lesiste (Beskidy Środkowe Foothills/Beskidy Lesiste Mts)

- Pogórze Bukowskie/Góry Sanocko-Turczańskie (Bukowsko Foothills/Sanok-Turka Mts)

- EV98 Lesko, 20 May 2014, 1 specimen, obs. E. Buga

- Pogórze Środkowebeskidzkie (Beskidy Środkowe Foothills)

- Pogórze Przemyskie (Przemyśl Foothills)

- FA20 Gruszowa, 1 Aug 2014, several specimens, obs. M. Obszarny

\section{Observations of preimaginal stages and host plants}

On the site in Lipnik, EA93: 49 59'33" N, 22 19'16" E, $274 \mathrm{~m}$ a. s. 1., wet meadow in an old orchard, bordering on a manor park; size c. 1.2 hectares (Fig. 2.), dusky crane's bill ( $G$. phaeum L.), marsh geranium, herb Robert geranium ( $G$. robertianum L.) occurred, whereas neither common stork's bill nor common rock-rose were found. In this place a single female was observed on 31 July, laying eggs on dusky geranium (G. phaeum L.), growing among low vegetation on the edge of an orchard. The eggs were laid on both upper and lower sides of leaves (Fig. 3.). At the same time, the first L1 caterpillar feeding on the lower side of leaf was observed. From 1 to 5 July, a total of 23 eggs were observed almost evenly divided between the upper side (12 eggs), and the lower side of leaves (11 eggs). At the same time, three more L1 caterpillars and one caterpillar at L2 stage were found (Fig. 4). On other species of geranium occurring on this locality, i.e. on marsh geranium and herb Robert geranium neither eggs nor larvae of $A$. agestis could not be seen. Mechanical cutting of a fragment of this meadow carried out on 6th August prevented any further observations on this locality.

In localities of Markowa, EA94: $50^{\circ} 01^{\prime} 37^{\prime \prime} \mathrm{N}, 22^{\circ} 18^{\prime} 52^{\prime \prime} \mathrm{E}, 230 \mathrm{~m}$ a.s.1., dry meadows, periodically used as pasture, bordering an orchard, c. 0.5 -hectare size - meadow geranium $(G$. pratense L.) was found, whereas no common stork's bill, common rock-rose or any other species of geranium were found. In this place females of 2 nd generation were observed laying eggs on meadow geranium. The eggs were laid separately, only on the leaves of host plants. The majority of 28 eggs (17 eggs) were found on the upper side of leaf blades, the remaining 11 eggs were found on the lower side of leaves. On a single plant, there was a maximum of 5 eggs found. On 5th July the first L1 caterpillar was found, feeding on the lower side of leaf of a meadow 
geranium plant. In period 6-8 August, six more caterpillars were found. After 9th August, the intensified cattle grazing on this locality prevented any further observations in this locality.

During the studies carried out on both localities no interaction between A. agestis larvae with ants was observed.

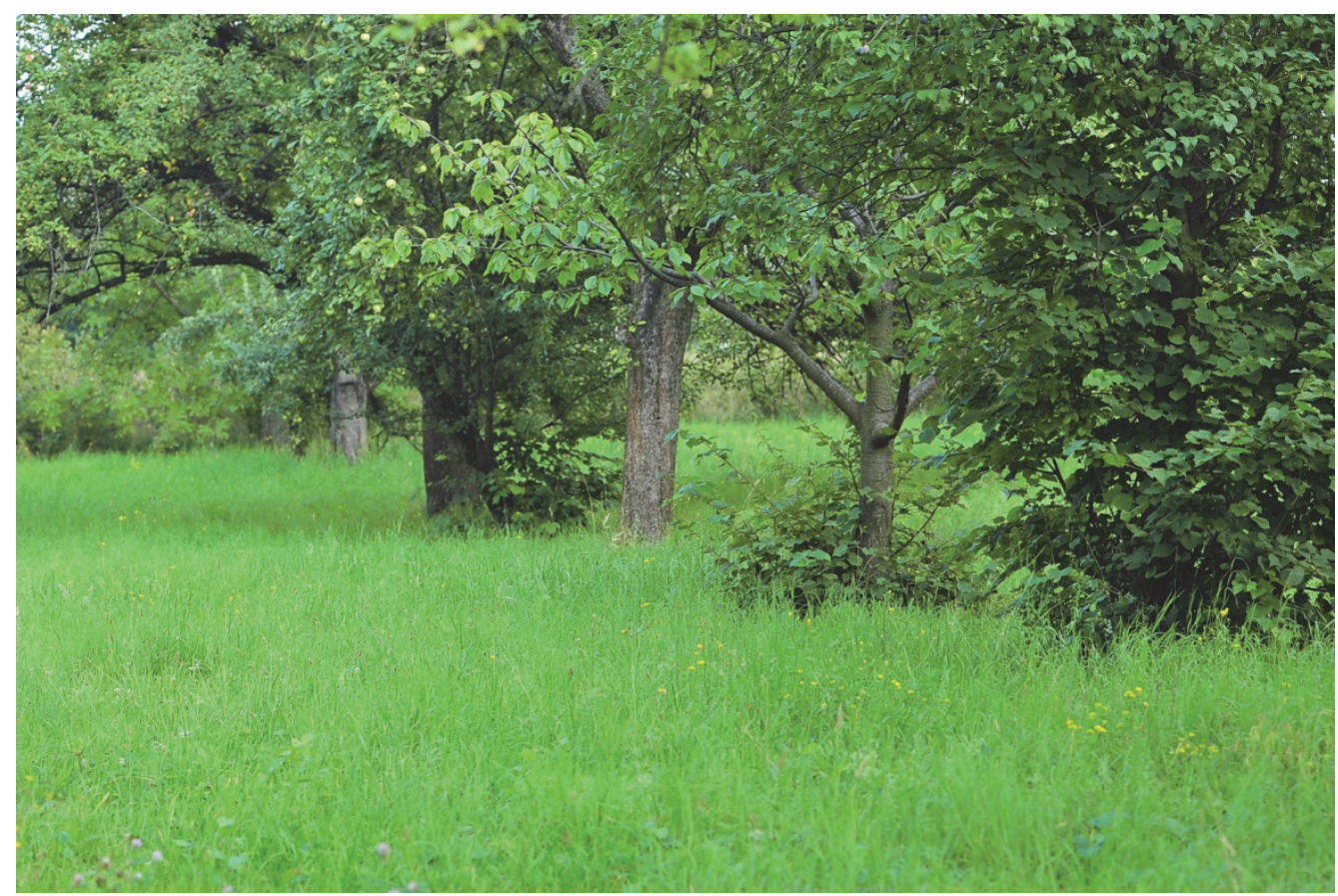

Fig. 2. Locality of Aricia agestis in Lipnik, 31 Jul 2012. Photo by J. Bury.
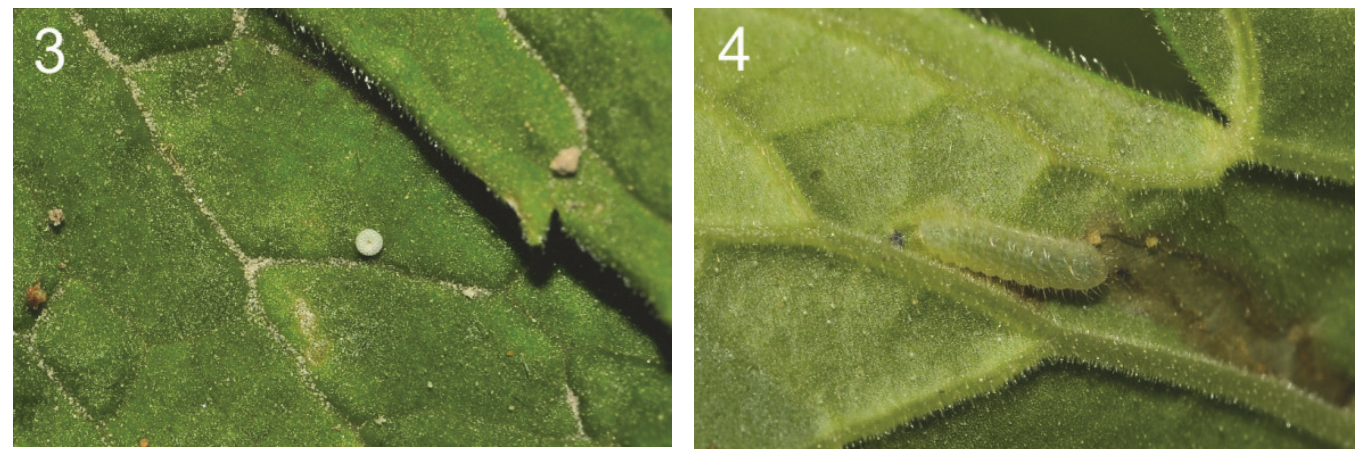

Fig 3 \& 4. Aricia agestis on Geranium phaeum at Lipnik stand; 3 - egg on leave, 31 Jul 2012, 4 - feeding caterpillar L2, 5 Aug 2012. Photos by J. Bury.

\section{DISCUSSION}

In the surveys of adult butterfly conducted in mountain and sub-mountain zones of Podkarpacie region from 2009 to 2014, A. agestis was found at 14 new sites in 11 UTM squares $(10 x 10 \mathrm{~km})$ located within seven mesoregions: Low Beskid Mts., Sanok-Turka Mts., Przemyśl Foothills, Dynów Foothills, Bukowsko Foothills, Jasło-KrosnoValley and Rzeszów Foreland, 
where in the past the species was known (few records only) mainly from Bieszczady Mts and Low Beskid Mts (Bielewicz 1973, Krzywicki 1982, Przybyłowicz 2000, Olbrycht \& Pączka 2004, KSIB 2014). In one of the last comprehensive study conducted in Poland in years 1985-1995 no locality of $A$. agestis in this part of Podkarpacie region was found (Buszko 1997). The species was also not found in majority of other polish mountains, for instance in polish part of Tatra Mts, and Karkonosze Mts (Krzywicki 1982, Wenta 2010, Čížek et al. 2015), but was systematically mentioned from Pieniny Mts. (Błeszyński et al. 1965, Adamski et al. 2010).

In the surveys of caterpillars two species of geranium were proved as the host plants of $A$. agestis - meadow geranium and dusky geranium. The most remarkable is the fact that the latter species has never been previously recorded as a feeding plant for A. agestis larvae.

The first of these two species is a common one occurring throughout Poland, whereas the second is relatively rarely found, its distribution range is limited to mountain and sub-mountain areas, and it is only sporadically noted in the lowlands. These areas are only occasionally penetrated by the plant, chiefly along river valleys and road shoulders. In Poland it reaches the northern limit of its distribution (Szafer et al. 1988, Zając \& Zając 2001, Nowak et al. 2011). Using the dusky geranium plants by $A$. agestis larvae has been made possible, probably owing to the close relationship with other species of geranium, and with common stork's bill with which it is almost identical in biochemical terms (Radulović \& Dekić 2013).

Discovering new, a typically mountain host plant of A. agestis can be explained in two ways: either this plant has been overlooked in the studies on the biology of this butterfly which is unlikely in the case of a species with such wide distribution in Europe, or there is an ongoing phenomenon of $A$. agestis adaptation to a new host plant, within the context of rapid climatic changes occurring within its area of distribution (Klimczuk 2005, Settele et al. 2008, Mallet et al. 2010, Kocsis \& Hufnagel 2011).

A similar process of adaptation of $A$. agestis to the new host plant has been observed during recent years, in the Great Britain. It led to an unexpectedly fast transformation in the population dynamics and habitat preferences. In the process, A. agestis - rarely and locally occurring species with relatively narrow habitat preferences, associated with thermophilous grasslands with common rock-rose, has adapted itself to inhabiting various meadow communities with certain proportion of geranium plants (Geranium spp.), principally dove'sfoot geranium, used as alternative host plants. In the Great Britain, such use of new resources by $A$. agestis has led to rapid broadening of its area of distribution, and to reversing the declining tendency in the number of colonies and population numbers (Parmesan 2006, Pateman at al. 2012).

In Poland, the use of dusky geranium as an alternative host plant by $A$. agestis when faced by limited access or lack of common rock-rose and common stork's bill in the habitat, opens the prospects of widening its occurrence into mountainous and sub-mountainous areas in the southern and southeastern parts of the country where this species was previously recorded only sporadically

Further studies on the biology and distribution of A. agestis in the Podkarpacie region and other mountain areas of southern Poland will permit explanation whether the new feeding adaptations do actually contribute to spreading the distribution area of the species in this part of Poland.

\section{ACKNOWLEDGEMENTS}

The author would like to thank those who contributed to this paper. In particular I thank Edwin Buga, Wojciech Guzik, Krzysztof Mazur, Mariusz Obszarny and Daniel Stasiowski for providing unpublished data on the distribution of $A$. agestis in Podkarpacie region (SE Poland). 


\section{REFERENCES}

Aagaard K., Hindar K., Pullin A. S., James C. H., Hammarstedt O., Balstad T. \& Hanssen O. 2002. Phylogenetic relationships in brown argus butterflies (Lepidoptera: Lycaenidae: Aricia) from north-western Europe. Biological Journal of the Linnean Society 75: 27-37.

ADAMSKI P., KOSIOR A. \& WiTKOWSKI Z. 2010. Zmiany fauny owadów zapylających w otoczeniu Zespołu Zbiorników Wodnych Czorsztyn - Niedzica - Sromowce Wyżne. In: SoJA R., KNUTELSKi S. \& BodZIARCZYK J. (eds), Pieniny - Zapora - Zmiany, pp. 185-193. Monografie Pienińskie 2: 1-329.

ALLAN P.B.M. 1949. Larval foodplants, a vade-mecum for the field lepidopterist. Watkins \& Doncaster, London, $126 \mathrm{pp}$.

Asher J. M., Warren M. S., Fox R., Harding P., Jeffcoate G. \& Jeffcoate S. 2001. The Millennium Atlas of Butterflies in Britain and Ireland. Oxford University Press, Oxford, $334 \mathrm{pp}$.

BIELEWICZ M. 1973. Motyle większe (Macrolepidoptera) Bieszczadów Zachodnich i Pogórza Przemyskiego. Roczniki Muzeum Górnośląskiego w Bytomiu, Przyroda 7: 1-170.

BŁESZYŃSKi S., RAZOWSKI J. \& ŻUKOWSKI R. 1965. Fauna motyli Pienin. Acta Zoologica Cracoviensia 10: $375-493$.

BURY J. 2010. Leksykon - motyle, pp. 137-171, In: BusZKO J., BURY J. \& WIATRAK Z. Najpiękniejsze motyle i trzmiele Podkarpacia. Libra, Rzeszów, $171 \mathrm{pp}$.

BusZKO J. \& MASŁOWSKI J. 1993. Atlas motyli Polski. Cześć I. Motyle dzienne (Rhopalocera). Image, Warszawa, 269 pp.

BuszKo J. \& MASŁowsKi J. 2008. Motyle dzienne Polski, Wydawnictwo "Koliber", Nowy Sącz, 274 pp.

BuszKo J. 1997. Atlas rozmieszczenia motyli dziennych w Polsce [A distribution atlas of butterflies in Poland] 1986-1995. Turples, Toruń, 170 pp.

BuszKo J. \& OlszewsKi P. 2010. Comparative study on the biology of Aricia agestis and Aricia artaxerxes (Lepidoptera). Acta Biologica Cracoviensia, Series Botanica 52 (suppl. 1): 50.

ČížEK O., MALKIEWICZ A., BeneŠ J. \& TARnAwSKi D. 2015. Denní motýli v Krkonoších, atlas rožšřření / Motyle dzienne w Karkonoszach, atlas rozmieszczenia. Správa KRNAP \& Dyrekcja KPN, 328 pp.

EBERT G. 1991. Die Schmetterlinge Baden-Württembergs. Band 2, Tagfalter II. Stuttgart (Ulmer), 535 pp.

FIEDLER K. 1991 [1989]. European and North West African Lycaenidae and their associations with ants. Journal of Research on the Lepidoptera 28: 239-257.

FIEDLER K. 1994. Lycaenid butterflies and plants: is myrmecophily associated with amplified hostplant diversity? Ecological Entomology 19: 79-82.

FIEDLER K. 1995. Associations of lycaenid butterflies with ants in Turkey. In: HesselBarTh G., van OORSCHOT H. \& WAgEnER S. (eds.), Die Tagfalter der Türkei unter Berücksichtigung der angrenzenden Länder, vol. 1, pp. 437450. Verlag S. Wagener, Bocholt.

FIEDLER K. 2006. Ant-associates of Palaearctic lycaenid butterfly larvae (Hymenoptera: Formicidae; Lepidoptera: Lycaenidae) - a review. Myrmecologische Nachrichten 9: 77-87.

FiedLeR K. \& HuMMeL V. 1995. Myrmecophily in the brown argus butterfly, Aricia agestis (Lepidoptera: Lycaenidae): Effects of larval age, ant number and persistence of contact with ants. Zoology 99: 128-137.

Fox R., Asher J. M., Brereton T., Roy D. B. \& WARren M. S. 2006. The state of butterflies in Britain and Ireland. NatureBureau, Newbury, 112 pp.

Fox R., Brereton T., Asher J. M., Botham M. S., Middlebrook I., Roy D. B. \& Warren M. S. 2011. The state of the UK's butterflies 2011. Butterfly Conservation and the Centre for Ecology and Hydrology, Wareham, Dorset, $16 \mathrm{pp}$.

GóRniCKi A. \& TOMASIAK Z. 2010. Motyle i trzmiele Podkarpacia. Oddział Przemyski Ligi Ochrony Przyrody, Przemyśl, 103 pp.

HeAth J., POllard E. \& ThOMAs J. A. 1984. Atlas of butterflies in Britain and Ireland. Viking, Harmondsworth, UK, 158 pp.

Hesselbarth G., van OORschot H. \& Wagener S. 1995. Die Tagfalter der Türkei: unter Berücksichtigung der angrenzenden Länder. 3 Vols. Verlag S. Wagener, Bocholt, Vol. (1+2): 1354 pp., 3: 847 pp.

KLIMCZUK P. 2005, The larval host plant of Polyommatus eroides (Frivaldszky, 1835), (Lycaenidae) from Poland with comments on the life history. Nota Lepidopterologica 28: 103-111.

KONDRACKI, J. 2002. Geografia regionalna Polski. PWN, Warszawa, 444 pp.

Kocsis M. \& HufNagel L. 2011. Impacts of climate change on lepidoptera species and communities. Applied Ecology and Environmental Research 9: 43-72.

KRZYWICKI M. 1959. Lycaenidae, Erycinidae. In: Klucze do oznaczania owadów Polski, part XXVII, (61-62). PWN, Warszawa, $64 \mathrm{pp}$.

KRZYWICKI M. 1963. Przyczynek do znajomości fauny Rhopalocera Tatr Polskich (Lepidoptera), Annales Zoologici 21: 151-222.

KrZYWICKI M. 1982. Monografia motyli dziennych Polski. Papilionoidea i Hesperioidea (Lepidoptera). Lublin, 364 pp., 168 map, 17 tabl., 4 tabele (msc.).

KSIB. MAPA BIORÓŻNORODNOŚCI [online], Krajowa Sieć Informacji o Bioróżnorodności. Available at http://baza.biomap.pl (16 Dec 2014).

KUBASIK W., RYBSKA E. \& WALCZAK U. 1996. Uwagi o motylach dziennych (Lepidoptera, Rhopalocera) Beskidu Niskiego. Wiadomości Entomologiczne 15: 59. 
KUDRNA O. 2002. The distribution Atlas of European Butterflies. Oedippus, 20: 1-343.

Kudrna O., Harpke A., LuX K., Pennerstorfer J., Schweiger O., Settele J. \& Wiemers M. 2011. Distribution atlas of butterflies in Europe. Gesellschaft für Schmetterlingschutz, Halle, Germany, 576 pp.

LAFRANCHIS T. 2007. Motyle dzienne. Przewodnik terenowy i klucz do rozpoznawania. Multico, Warszawa, 379 pp.

Mallet J., WynNe I. R. \& Thomas C. D. 2010. Hybridisation and climate change: brown argus butterflies in Britain (Polyommatus subgenus Aricia). Insect Conservation and Diversity 3: 192-199.

NowaK T., Urbisz A., Kapusta P. \& TOKARSKA-GuZiK B. 2011. Distribution patterns and habitat preferences of mountain vascular plant species in the Silesian Uplands (Southern Poland). Polish Journal of Ecology 59: $219-234$.

Olbrycht T. \& PAcCZKA G. 2004. Motyle dzienne (Rhopalocera) Rzeszowa. Zeszyty Naukowe PołudniowoWschodniego Oddziału Polskiego Towarzystwa Inżynierii Ekologicznej i Polskiego Towarzystwa Gleboznawczego, Oddział w Rzeszowie, 5: 21-26.

OlBRYCHT T. \& BURY J. 2010. Motyle dzienne (Rhopalocera) okolic Husowa. In: UCHMANN A. (ed.) Husów - wieś na Pogórzu Dynowskim w ujęciu monograficznym, pp. 104-112, Zeszyty Stowarzyszenia Społeczno-Kulturalnego im. Wincentego Stysia, (2). Stowarzyszenie Społeczno-Kulturalne im. Wincentego Stysia, Urząd Gminy Markowa. Husów, 591 pp.

OlBRYCHT T. \& BURY J. 2011. Specjalny obszar ochrony siedlisk Nad Husowem (PLH180025). In: RogAŁA, D., MARCElA, A. (eds.), Obszary NATURA 2000 na Podkarpaciu, pp. 236-239. RDOŚ [Regionalna Dyrekcja Ochrony Środowiska], Rzeszów, 351 pp.

Olbrycht T., BuRY J. \& BABUla P. J. 2005. Motyle dzienne (Rhopalocera) gminy Markowa. Zeszyty Naukowe Południowo-wschodniego Oddziału Polskiego Towarzystwa Inżynierii Ekologicznej i Polskiego Towarzystwa Gleboznawczego, Oddział w Rzeszowie, 6: 77-85.

OLSZEWSKI 2010. Bionomia modraszka agestis (Aricia agestis) oraz modraszka artaxerxes (Aricia artaxerxes). Master Thesis. Nicolaus Copernicus University. Faculty of Biology and Earth Sciences, Dpt. of General and Molecular Biology, 46 pp.

Pateman R. M., Hill J. K., Roy D. B., Fox R. \&Thomas C. D. 2012. Temperature-dependent alterations in host use drive rapid range expansion in a butterfly. Science 336: 1028-30.

PAWŁowsKi J. 2009. Cenne bezkręgowce naziemne Magurskiego Parku Narodowego i terenów ościennych. In: GóRecki A. \& ZEMAneK B., (eds), Magurski Park Narodowy. Monografia Przyrodnicza, pp. 132-146. Krempna - Kraków, 269 pp.

PAWŁOWSKI J. 2011. Karpaty polskie jako ostoja i azyl zagrożonych gatunków bezkręgowców. Polish Carpathian Mts as a refugium of the endangered species of invertebrates. Roczniki Bieszczadzkie 19: 231-245.

PrZYBYŁowiCZ Ł. 2000. Motyle (Lepidoptera) Bieszczadów Zachodnich. Monografie Bieszczadzkie 8: 251-303.

PARMESAN C. 2006. Ecological and Evolutionary Responses to Recent Climate Change. Annual Review of Ecology, Evolution, and Systematics 37: 637-669.

RADUlović N. S. \& DeKIĆ M. S. 2013. Volatiles of Geranium purpureum Vill. and Geranium phaeum L.: Chemotaxonomy of Balkan Geranium and Erodium Species (Geraniaceae), Chemistry \& Biodiversity 10: 20422052.

ROMANISZYN J. \& SCHILlE F. 1929. Fauna motyli Polski. I. Prace monograficzne Komisji Fizjograficznej 6: 1-552.

SAÑUdo-Restrepo C. P., DinCĂ V., TAlaVERA G. \& Vila R. 2012 Biogeography and systematics of Aricia butterflies (Lepidoptera, Lycaenidae), Molecular Phylogenetics and Evolution 66: 369-379.

SCHEFFNER J. 1925. Die Schmetterlinge aus der Umgebung von Olchowa. I. Teil: Die Tagfalter. Societas entomologica 40: $38-39$.

Settele J., Kudrna O., Harpke A., Kuehn I., van SwaAy C., Veronik R., Warren M., Wiemers M., Hanspach J., Hickler T., Kuehn E., VAn Halder I., Veling K., Vliegenthart A., Wynhoff I. \& Schweiger O. 2008. Climatic Risk Atlas of European Butterflies, Biorisk 1 (Special Issue), 710 pp.

SiELEZNiEW M. \& DZIEKAŃSKA I. 2010. Motyle dzienne. Multico, Warszawa, 335 pp.

SWAAY C. A. M. van \& WARREN M. 1999. Red data book of European butterflies (Rhopalocera). Nature and Environment, No 99. Council of Europe Publishing, Strasbourg, 260 pp.

SwaAy C. A. M. van, Cuttelod A., Collins S., Maes D., Lopez Munguira M., Šašić M., SetTele J., Verovnik R., Verstrael T., Warren M., Wiemers M. \& Wynhof I. 2010. European Red List of Butterfies Luxembourg, Publications Office of the European Union, $47 \mathrm{pp}$.

SwaAy C. A. M. van, WARren M. \& Grill A. 1997. Threatened butterflies in Europe: Provisional Report. Wageningen, the Netherlands: De Vlinderstichting (Dutch Butterfly Conservation), (Report no. VS97.25) and Wareham, UK: British Butterfly Conservation.

SZAFER W., KUlCZYŃSKi S. \& PAWŁowSKi B. 1988. Rośliny Polski. I. PWN, Warszawa, 464 pp.

TARrier M. \& Delacre J. 2008. Les Papillons de jour du Maroc. Guide d'identification et de bio-indication. Biotope, Mèze (Collection Parthénope), Muséum national d'Histoire naturelle, Paris, 480 pp.

TOLMAN T. \& LEWINGTON R. 1997. Butterflies of Britain and Europe. Harper Collins, London, UK, 320 pp.

Tshikolovets V. V. 1998. The butterflies of Palaearctic Asia. Vol. 1. The Butterflies of Turkmenistan. Konvoj Ltd., Brno, 237 pp. 
Tshikolovets V. V. 2003. Butterflies of Eastern Europe, Urals and Caucasus: An Illustrated Guide. Konvoj Ltd., Kyiv-Brno, 176 pp.

TShiKolovets V. V. 2005. The butterflies of Palaearctic Asia. Vol. 6. The Butterflies of Kyrgyzstan. Konvoj Ltd., Brno-Kyiv, 512 pp.

Tshikolovets V. V., Yakovlev R. V. \& Kosterin O. 2009. The butterflies of Palaearctic Asia. Vol. 7. The Butterflies of Altai, Sayans and Tuva (South Siberia). Konvoj Ltd., Kyiv-Pardubice, 374 pp.

Tuzov V. K., Bogdanov P. V., DevyatKin A. L., KaABak L. V., Korolev V. A., Murzin V. S., Samodurov G. D. \& TARASOV E. A. 2000. Guide to the butterflies of Russia and adjacent territories (Lepidoptera, Rhopalocera). Hesperiidae, Papilionidae, Pieridae, Satyridae. Volume 2. Pensoft, Sofia-Moscow, 580 pp.

WARECKI A. 2010. Motyle dzienne Polski Atlas bionomii. Wydawnictwo Koliber, Nowy Sącz, 320 pp.

Wenta J. 2010. Motyle Tatrzańskiego Parku Narodowego. Wydawnictwo Tatrzańskiego Parku Narodowego, Zakopane, $175 \mathrm{pp}$.

WIECH K. \& ZIĘBA A. 2010. Motyle i trzmiele na bieszczadzkich kwiatach. Bieszczadzki Park Narodowy, Ustrzyki Górne, 199 pp.

WitKOWSKi Z. J., KRÓL W. \& SOLARZ W. 2003. Carpathian List Of Endangered species. WWF and Institute of Nature Conservation, Polish Academy of Sciences, Vienna-Kraków, 84 pp.

ZAJĄC, A. \& ZAJĄC M. 2001. Distribution Atlas of Vascular Plants in Poland. Pracownia Chorologii Komputerowej Instytutu Botaniki Uniwersytetu Jagiellońskiego, Kraków, 716 pp.

\section{STRESZCZENIE}

\section{[Nowe dane o Aricia agestis (Lepidoptera: Lycaenidae), jego biologii i występowaniu w regionie polskiego Podkarpacia]}

Aricia agestis (Denis \& Schiffermüller, 1775) (Lycaenidae) jest szeroko rozmieszczonym i często spotykanym gatunkiem motyla, jednakże jego biologia w warunkach krajowych jest relatywnie słabo poznana. Za rośliny żywicielskie gatunku na terenie Polski uznawane były do tej pory Helianthemum nummularium L. (Cistaceae) oraz Erodium cicutarium L., Geranium pratense L., Geranium sanquineum L. i Geranium pusilum L. (Geraniaceae), jednakże brak było szczegółowych danych pochodzących z rejonów górskich i podgórskich, gdzie gatunek znany był z kilku izolowanych stanowisk. W latach 2009-2014 na Podkarpaciu stwierdzono liczne nowe kolonie $A$. agestis. Ponadto w trakcie obserwacji prowadzonych w środkowej i południowej części regionu w 2012 roku po raz pierwszy zaobserwowano stadia preimaginalne - jaja i gąsienice (L1 \& L2) A. agestis na nowej roślinie żywicielskiej Geranium phaeum L. w miejscowości Lipnik (EA93), położonej na pograniczu Pogórza Dynowskiego oraz Kotliny Sandomierskiej. Stwierdzono również wykorzystywanie Geranium pratense L. jako rośliny żywicielskiej tego gatunku na stanowisku w Markowej (EA94). Konkludując, można stwierdzić, że na Podkarpaciu, a w szczególności w rejonach górskich i podgórskich regionu, stwierdza się wzrost ilości znanych kolonii A. agestis. Ponadto na terenie Podkarpacia odkryto dotychczas nieznaną roślinę żywicielską tego gatunku - Geranium phaeum L. 